\title{
Strategic Planning and Competitive Advantage of ICT Small and Medium Enterprises in Kenya
}

\author{
Zachary B. Awino \\ University of Nairobi, Kenya \\ E-mail: zb.awino@gmail.com
}

Received: April 29, 2013 Accepted: June 18, 2013 Published: June 30, 2013

doi: 10.5296/bmh.v1i1.3942ＵRL: http://dx.doi.org/10.5296/bmh.v1i1.3942

\begin{abstract}
The Paper is the research findings on the role of strategic planning and competitive advantage of ICT Small and Medium Enterprises in Kenya. Literature suggests that the contemporary business environment in which organisations operate is increasingly becoming uncertain and unpredictable. Significant changes are mostly driven by technological changes, globalisation and trade liberalisation. As a result, like large enterprises, SMEs are facing new and unexpected challenges that threaten their competitiveness. While most countries acknowledge the critical role that SMEs contribute to their economies, both as an engine of growth and sustainable development, many questions still remain unanswered as to the determination of the critical challenges facing SMEs and how these challenges could be addressed to improve their competitiveness. These challenges have increased the need for empirical information which is essential for decision making in addressing issues that are likely to enhance SMEs survival and growth. It is noted that there has been no adequate research studies on the role of strategic planning and competitive advantage of SMEs. This study contributes to the need to address the research gaps and thus explored the role of strategic planning and competitive advange of SMEs in Kenya. The study population consisted of 238 ICT SMEs from Nairobi and its environs. A sample size of 146 firms constituting 61 per cent of the total population was selected through stratified sampling. The study aimed to collect data from 438 respondents from top, middle and lower management teams. Structured questionnaires with closed and open ended questions was used for data collection, 239 responses were received from 123 ICT firms a response rate of 55 per cent and 84.2 per cent respectively. Key characteristics of strategic planning including formality, environmental analysis processes both internal and external orientations, strategies adopted, and implementation and control were recorded. Data analysis was done using descriptive statistics, factor analysis, t-test, ANOVA, correlation, correlation matrixes and regression analysis. The key findings revealed
\end{abstract}




\section{Macrothink}

that strategic planning has significant and positive influence in performance of SME's. The test of hypothesis revealed that strategic planning has positive and significant influence on competitive advantage. The study demonstrated strategic planning as a learning tool and a strategic resource which is consistent with the underlying assumptions of resource based theory, systems theory, chaos theory and balanced score card model assumptions. It is envisaged that, this kind of research is likely to generate useful discussions on the role of strategic planning and performance, of SMEs. It is apparent that entrepreneurs of SMEs cannot ignore strategic planning as significant changes in competitive advantage is the result of change or effective application of strategic planning. Policy makers and academicians may need to address the capacity needs of SMEs and develop strategic planning model that address the challenges that SMEs encounter in a dynamic environment.

Keywords: Strategic Planning, Competitive advantage, ICT, SMEs, Kenya 


\section{Introduction}

According to Raduan, Jegak, Haslinda and Alimin (2009), a business that does something that is distinctive and difficult to replicate is competitive advantage and is likely to be more profitable than its rivals. Pearce and Robinson, 2011; Schwenk and Shrader , 1993; Raduan et al. 2009) assert that from a resource-based view, strategic planning can result in strategic change which may increase strategy-environment fit, hence can become a source of sustained competitive advantage especially when strategic planning system improves flow of products and services between manufacturers and users.

Metcalfe, Ramlogan and Uyarra (2003) argue that competitiveness is embodied in the characteristics of the firm namely; (a) the current efficiency and effectiveness of the use of resources; (b) the willingness and the ability to relate profitability to growth of capacity (c) the ability to innovate to improve technology and organisation and thus improve efficiency and effectiveness.

The scholars aver that entrepreneurship and the introduction of new productive combinations and innovation is the driving force that continually creates new competitive advantages and opportunities for profit and growth and that it is up to the SMEs to implement competitive business operating practices and business strategies.

The internationalisation of economy, the frequent and uncertain change, the greater competition among firms, the need for continuous innovations, and the growing use of information technologies force companies to face the challenge of improving their competitiveness. These difficulties are greater for SMEs because their economies of scale and their resources are less than those of large firms. Pralahad and Hamel (1990) emphasised the link between core competencies and competitiveness of an organization. While, Wernerfelt, (1984) asserts that high performance of SME is explained primarily by the strength of a firm's resources, and not by the strength of its market position.

\section{Strategic Planning and Competitive Advantage in SMEs}

While planning in large organisations has been researched extensively, resulting in many prescriptions, models and concepts (Jennings and Beaver 1997), the use and application of the planning process in small firms is still the subject of on-going debate (O'Neill, Saunders and Hofman 1987). Pushpakumari and Athula (2008), argue that SMEs often do not have the means to ensure continuous successful implementation of strategic planning as they maintain lower levels of resources, have limited access to human, financial and customer base and less-developed management capacity and administrative systems. Research findings reveal that, generally, funding remains a necessary but not sufficient condition for a viable SME development. Management problems that manifest in many ways like: lack of capacity; lack of clear vision; lack of business plans and business strategy; and poor strategy implementation are critical for the performance and survival of SMEs (Gerber, 2001). According to Antony and Onugu (2005), unlike large enterprises, SMEs are characterised by their flexibility, responsiveness, pursuit of opportunities, risk- taking, innovation, unconventional thinking and creativity. According to RBV, chaos and contingency theories 
these are strategic resources that can be exploited by SMEs to adapt to the ever changing environment and to become more competitive and responsive to customer needs and requirements.

Comprehensive reviews of the small business literature suggest that, ceteris paribus, strategic planning and competitive advantage is generally more common in better-performing enterprises (Hormozi, Sutton, McMinn, and Lucio, 2002; Lurie, 1987; Miller \& Cardinal, 1994; Schwenk and Shrader, 1993). Several scholars (Berman, Gordon, and Sussman, 1997; Bracker, Keats, and Pearson, 1988; Carland and Carland, 2003; Gibson and Cassar, 2005) argue that small businesses that strategically plan are more likely to be innovative, achieve higher sales growth, and higher returns on assets, higher profit margins and higher employee growth and above all gain competitive advantage. According to, Gibson and Cassar (2002), planning in small firms is mostly adaptive in nature, short-term oriented and concerned with the manipulation of scarce resources.

Furthermore, planning in small firms is generally typified by intense personalisation and is highly influenced by the preferences, experiences, attitudes, prejudices and general personality sets of the firm. Thus the existence of diverse planning processes in small businesses should be expected but with little or no resemblance to the planning process found in large organisations.

\section{The Kenya SMEs Sector}

Small and Medium Enterprises are considered as the most prolific source of employment, with the ability to spread investment across the country (Sessional Paper No.2, 2005). The sector is noted a provider of goods and services, and a driver in promoting competition and innovation, enhancing the enterprise culture necessary for private sector development and industrialisation (Republic of Kenya). Likewise, the SMEs sector employs 74\% of the labour force and contributes over 18\% of the country's GDP. In Kenya, a small enterprise consists of those firms with 10-50 employees, annual turnover of between 6,000 USD and 60,000 USD and investment of between 60,000 USD and 240,000 USD. A medium-size enterprise would have 50-100 employees, annual turnover of between 60,000 USD to 10,000,000 USD.

Since Independence, the government has recognised the potential of the Small Enterprise (SE) sector in employment and poverty reduction. This objective has been outlined in Sessional Paper No. 1 of 1986 on Economic Management for Renewed Growth, Sessional Paper No. 2 of 1996 on Industrial Transformation to the year 2020, the Sessional Paper No. 2 of 2005 on the development of MSEs for Employment and Wealth Creation (Republic of Kenya 1986, 1996, 2005). It recognised the need to establish and maintain a conducive environment for the graduation of SMEs to have more capacity to produce high quality products and create sustainable employment opportunities.

Kenya Vision 2030 has identified Information and Communication Technology (ICT) as a key engine of growth, as it is a key investor in people services and networks. The development of SMEs in ICT sector is important in contributing to the attainment of Vision 2030’s strategic objective of middle-income industrialised status by 2030 . 


\section{Macrothink}

Despite the numerous policy prescriptions, and the overwhelming evidence on the role and potential of SMEs in wealth creation, the sector is faced with various challenges and constraints that inhibit or constrain its growth. These include among others, unfavourable policy environment, access to financial resources, inadequate access to skills and technology, limited access to infrastructure, inadequate business skills, limited linkages with large enterprises and limited access to information, and lack of knowledge about customer's needs(Baseline Survey, 1999 and Sessional Paper No. 2 of 2005). The effect of this is less growth in the SME sector and high failure rate. Grant (2008) asserts that knowing what customers want and how a firm survives competition are prerequisites for success. SMEs can use strategic planning tool to develop strategies and gain competitive advantage. According to The Economist (2012), the link between small firms and jobs growth relies entirely on new start-ups, which are usually small. Given the above scenario the objective of this study was to establish whether strategic planning influences competitive advantage of ICT SMEs performance in Kenya.

\section{Conceptual Framework}

This study was guided by the conceptual framework in Figure 1 below which also shows the operationalisation of the study variables. This model is based on the basic premises of the strategic planning proposed by Berry (1998). Berry (1998) argues that whether formal or informal, strategic planning is carried out and that substantive analytical elements of the process include; scanning the environment; analysing competitive activity; assessing strengths and weaknesses; developing long term objectives and short term operational plans; and reviewing and revising plans. Similarly, the way in which the strategy implementation process is organised will very likely have an influence on competitive advantage. 


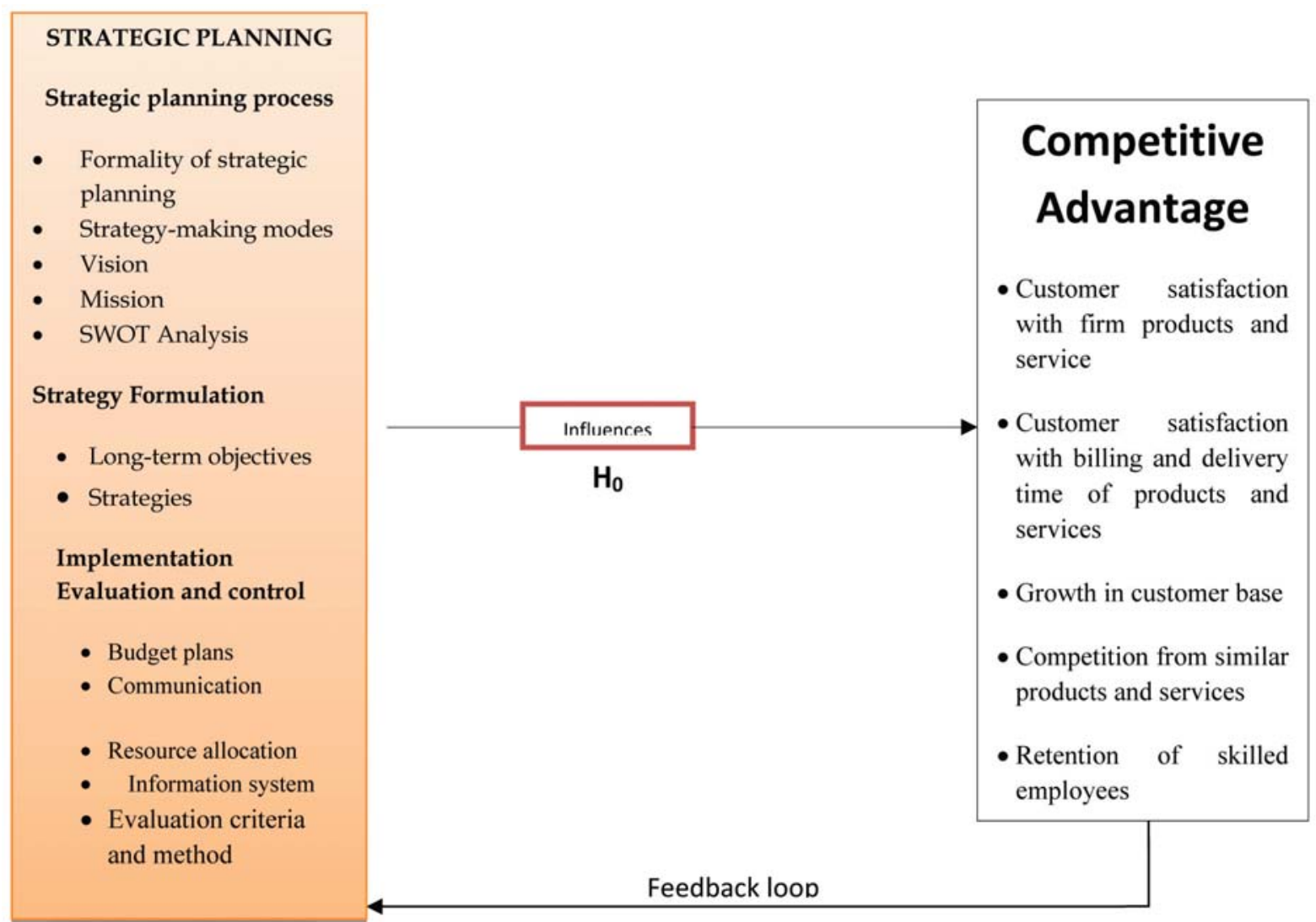

Figure 1. Conceptual framework and operationalisation of variables

$\mathbf{H}_{\mathbf{0}}$ : There is no significant relationship between strategic planning and competitive advantage.

The hypothesis highlights the relationship between strategic planning (processes and actions) and competitive advantage. It is supposed that effective application of strategic planning will have a positive and significant influence on the improvement of competitive advantage and performance of SMEs.

To test hypothesis, the following regressions model is used: Model I, $y_{1}=p_{0}+p_{1} x_{1+} \varepsilon$ where $\mathrm{y}_{1}=$ competitive advantage, $\mathrm{x}_{1}=$ strategic planning, $\beta_{1}=$ the change in the dependent variable for a unit change in the independent variable, and $\epsilon$ is the error term,

\section{Methodology}

A cross-sectional study was determined to be useful in collecting descriptive data on strategic planning practices and performance of SMEs. It represents perceptions of employees at three different levels comprising top, middle and lower management and provides a snapshot of their views as they exist in SMEs. The survey research design thus sought to identify the 
extent of strategic planning and competitive advantage. This approach is in line with previous empirical research (Beaumaster, 1999; Njanja, 2009; \& Mohutsiwa, 2012), which used a cross-sectional study in a survey to investigate management practices affecting SMEs in Kenya and the link between strategic entrepreneurship and performance of SMEs in South Africa.

The target population was 238 ICT SMEs in Nairobi drawn from the Computer Society of Kenya (CSK) and the 2010 Mocality Directory of Kenya (MDK). Firms under study were in the business of software development, internet services, software consultancy, hardware assembly and repairs, and back office operations (call centres and business process outsourcing). The small firms employing 10-100 persons were chosen for the study and stratified into age as shown below

Table 1. Population Strata

\begin{tabular}{ll}
\hline Age Stratum & Population \\
\hline $1-5$ & 88 \\
$5-10$ & 69 \\
$10-15$ & 48 \\
15 and Above & 33 \\
Total & 238 \\
\hline
\end{tabular}

Both qualitative and quantitative data were collected through primary and secondary data sources. Both forms of data were required, to gain a deeper insight and a better interpretation of the quantitative data. The current study utilised a questionnaire and interview guide as used in various previous research projects (Lumpkin and Dess, 2001; Lumpkin, 1998). The questionnaire consisted primarily of close-ended questions presented on a five-point Likert type measurement scale. The primary data was key to the current research as it provided information that addressed the research objectives.

Furthermore, a semi-structured interview guide was used to solicit for additional information that were thought would enrich the research outputs. According to (Cooper and Schindler, 2006; Kothari 2004) an interview guide consists of a set of questions that the interviewer asks when conducting an interview

The primary research data was collected using survey method from three categories of employees, namely the owners and top managers, middle level managers and lower level employees of the ICT SMEs in Nairobi using a questionnaire that comprised both structured and unstructured questions and supported by an interview guide. The questionnaires were hand delivered to each of the respondent organisation with an introductory letter from the university as well as evidence of a research permit from the National Council for Science and Technology. The researcher participated in data collection exercise and engaged the services of four research assistants who after being trained assisted in the distribution, collection of 


\section{Macrothink}

Business and Management Horizons

ISSN 2326-0297 2013, Vol. 1, No. 1

the fully completed questionnaires as well as follow up on gaps that were identified in the questionnaires. The data collection activity commenced in mid-June and was completed in mid-August, 2012.

\section{Data Analysis}

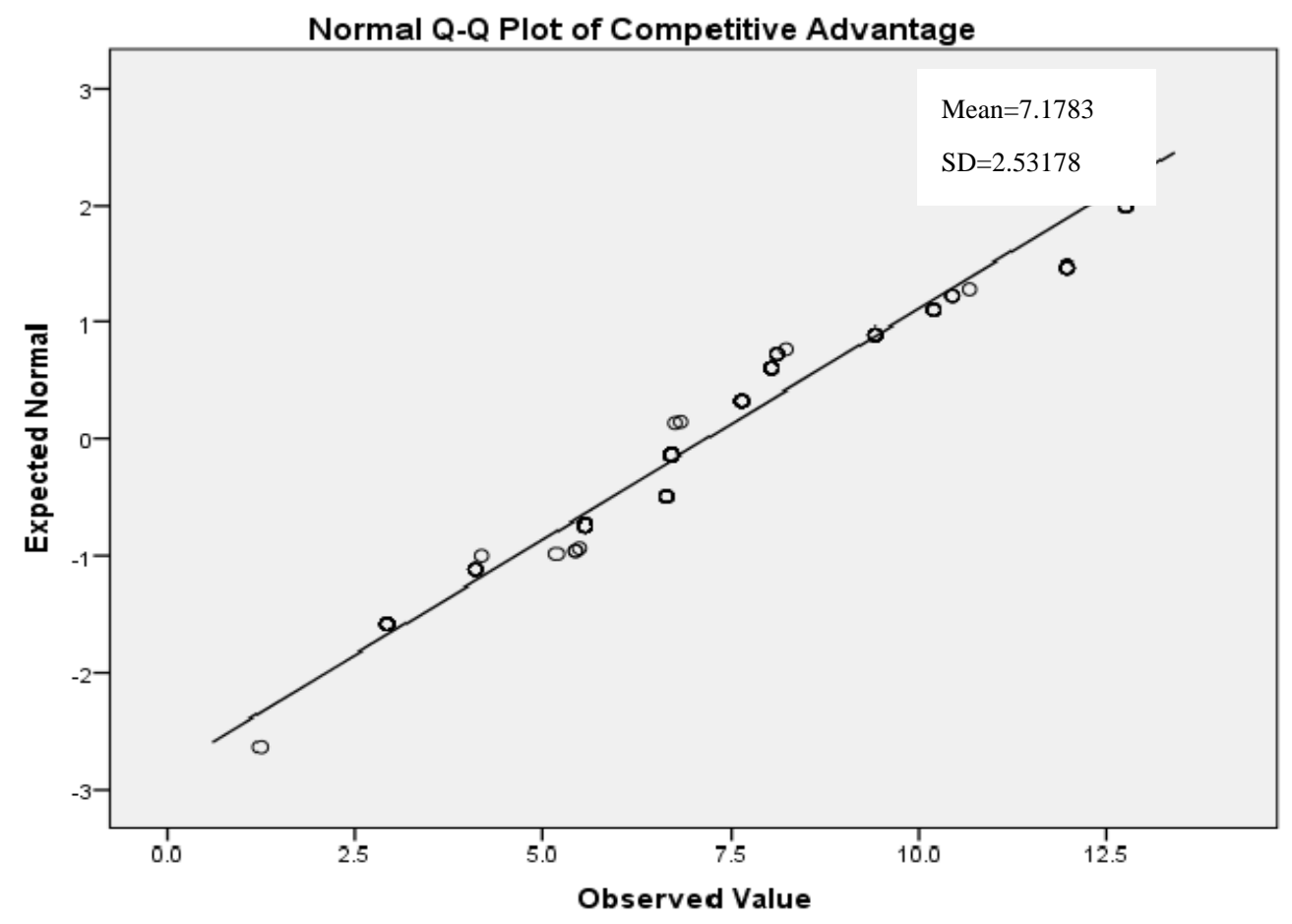

Figure 2. Q-Q plot of competitive advantage

\section{Statistical Modelling - Competitive Advantage versus Strategic Planning}

The study continued to examine the extent to which strategic planning correlated with firm competitive advantage. This served to address the main objective of the study. Figure 2 shows a scatter plot of the two variables that suggests a positive linear relationship between firm competitive advantage and strategic planning practices. This means that a firm achieves a higher competitive advantage with a higher level of strategic planning practices. 


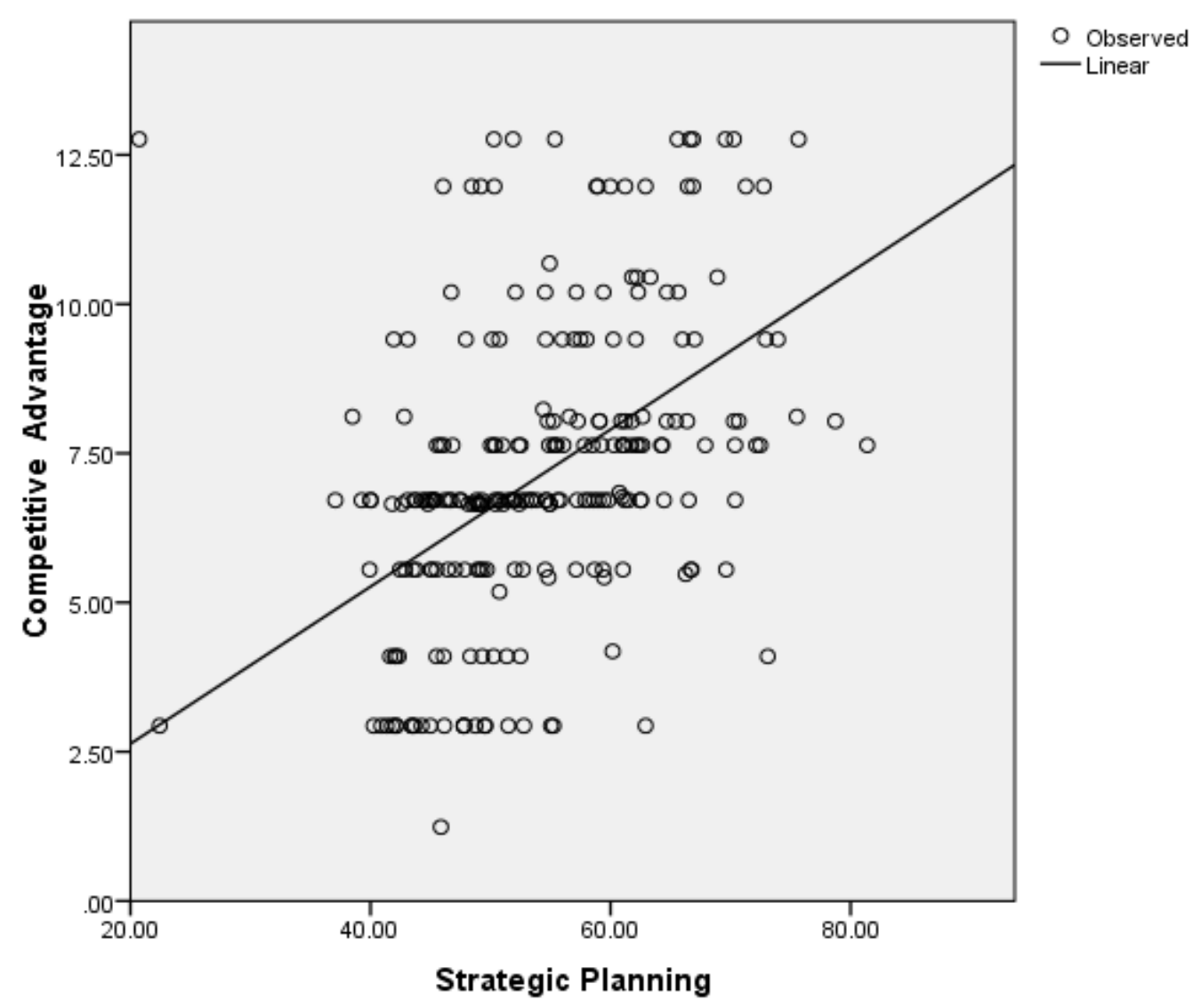

Figure 3. Scatter plots of competitive advantage and strategic planning

Based on the scatter plot revelation, a linear regression analysis was carried out to determine the nature of the relationship between a firm's competitive advantage and strategic planning. The results indicate a positive, moderate linear relationship with a correlation coefficient of $r=0.412$. The coefficient of determination $r^{2}$, which measures the goodness of fit was determined as $r^{2}=0.170$, which means that $17 \%$ of the corresponding change in the firm competitive advantage can be explained by the modely $\boldsymbol{y}_{1}+p_{0}+p_{1} x_{1+}$. These analyses are shown in Table 2. 


\section{IIMacrothink}

Table 2. Model summary of competitive advantage versus strategic planning

\begin{tabular}{lll}
\hline Model & R & R Square \\
\hline 1 & $.412^{\mathrm{a}}$ & .170 \\
\hline
\end{tabular}

a. Predictors: (Constant), Strategic Planning

The study further examined the significance of the overall model I, $y_{1}-p_{q}+p_{1} x_{1+} \in$ (see table 3) where $y_{1}=$ competitive advantage, $x_{1}=$ strategic planning, $\beta_{1}=$ the change in the dependent variable for a unit change in the independent variable, and $\epsilon$ is the error term, was examined. The Analysis of Variance (ANOVA) for the significance of the model that $\mathrm{x}_{1}$ is significant at $5 \%$ level of significance $(\sigma=0.05)$ the value of $p=0.000$ means that the null hypothesis is rejected. This implies that $\mathrm{x}_{1}$ (strategic planning) is significant in explaining $y_{1}$ (competitive advantage) and that the model $y_{1}=\beta_{0}+\beta_{1} x_{1+} \epsilon$ is significantly fit at $5 \%$ level of significance.

Table 3. ANOVA ${ }^{\text {a }}$ of competitive advantage versus strategic planning

\begin{tabular}{|c|c|c|c|c|c|}
\hline Model & $\begin{array}{l}\text { Sum of } \\
\text { squares }\end{array}$ & df & $\begin{array}{l}\text { Mean } \\
\text { square }\end{array}$ & $\mathbf{F}$ & Sig. \\
\hline 1 Regression & 258.863 & 1 & 258.863 & 48.433 & $.000^{\mathrm{b}}$ \\
\hline Residual & 1266.698 & 237 & 5.345 & & \\
\hline Total & 1525.560 & 238 & & & \\
\hline
\end{tabular}

a. Dependent Variable: Competitive Advantage

b. Predictors: (Constant), Strategic Planning

Further analysis as shown in Table 4 shows the beta coefficient parameters of the test of the significance of the constant $p_{0}$ and $x_{1}$ in the model $y_{1}=p_{0}+p_{1} x_{1+} s$. The results indicate an insignificant constant of $\beta_{0}=1.251$ and a $p=0.149$. The coefficient $\beta_{1}=0.109$ suggests that for a unit change in strategic planning practices, there is 0.109 positive change in the competitive advantage of a firm. Further, it is observed that the strategic planning 
variable is significant as the $p$ value $=0.0001$ is less than the level of significance $\alpha=0.05$. This suggests that strategic planning is a variable that could be used to assess the competitive advantage of a firm.

Similar studies by Lieldholm, 2001; and Kargar and Parnell (1996) concluded that strategic planning is a source of competitive advantage and that the sector in which a firm operates significantly explains comparative advantage of the industry. This suggests that strategic planning has a significant positive effect on organisational performance (Andersen, 2000).

Table 4. Coefficient ${ }^{\mathrm{a}}$ parameters of competitive advantage versus strategic planning

\begin{tabular}{|c|c|c|c|c|}
\hline \multirow[b]{2}{*}{ Model } & \multicolumn{2}{|c|}{ Coefficients } & \multirow{3}{*}{$\begin{array}{l}\text { t } \\
1.447\end{array}$} & \multirow{3}{*}{$\begin{array}{l}\text { Sig. } \\
.149\end{array}$} \\
\hline & B & Std. Error & & \\
\hline 1 (Constant) & 1.251 & .865 & & \\
\hline Strategic & .109 & .016 & 6.959 & .000 \\
\hline Planning & & & & \\
\hline
\end{tabular}

a. Dependent Variable: Competitive Advantage

\section{Conclusion}

The study examined strategic planning practices among ICT SMEs. The key strategic planning variables examined entailed: formality of strategic planning; strategic planning processes; strategy adoption, and strategy implementation and control.

The results suggest that a significant number of SMEs in the ICT sector employ strategic planning practices and have written strategic plans. Previous studies suggest that firms having formal strategic planning outperform those that do not (Allison and Kaye, 2005; Akinyele 2007). Having written strategic plans for instance, suggests that a firm has a framework from which it can measure and evaluate its progress and direct and control its business activities. In this regard, strategic planning and its processes can be considered as a learning tool for SMEs. This is consistent with the underlying theories, namely; resource-based view (RBV), systems theory, and chaos theory that advance that formal strategic planning and its underlying processes can constitute a source of sustained competitive advantage.

\section{Implication of the Study on Policy, Theory and Practice}

This study not only contributes more empirical data to existing research on the role of strategic planning and performance of SMEs, but also more importantly gives remarkable guidance in terms of strategic planning activities to the owners and managers of SMEs. Secondly, based on the strategy making modes, managers can learn to involve employees in the strategic planning process, analyse internal and external environments with the aim of identifying and strengthening key capabilities and investing in information technology to 
facilitate generation of information for decision making. Thirdly, development of long- and short-term budgets and targets facilitates implementation and control, and acts as a performance management tool. Fourthly, investment in high skilled employees with high levels of education improves firm productivity and long-term performance and sustainability.

Lastly, the result on firm characteristics adds to the ongoing debate on the classification of SMEs. This has implications on policy aspects as appropriate classification of SMEs may require different policy prescriptions. As illustrated above, the study achieved the set objectives by providing answers to the set objectives and assessing the hypotheses. In so doing, it has addressed the concerns of scholars, policy makers and practicing managers, and helped close some of the apparent information gaps and, hence, made its contribution to the field of strategic management.

\section{References}

Akinyele, S. T., \& Fasogbon, O. I. (2007). Impact of Strategic Planning on Organisational Performance and Survival. Research Journal of Business Management, 1, 62-71. http://dx.doi.org/10.3923/rjbm.2007.62.71

Allison, M., \& Kaye, J. (2005). Strategic Planning for Non-Profit Organizations: A Practical Guide and Workbook. Wiley Publishers, New York.

Andersen, T. J. (2000). Strategic Planning: Autonomous Actions and Corporate Performance. Long Range Planning, 33, 184-200. http://dx.doi.org/10.1016/S0024-6301(00)00028-5

Berman, J. A., Gordon, D. D., \& Sussman, G. (1997). A Study to Determine the Benefits Small Business Firms Derive from Sophisticated Types of Planning. The Journal of Business and Economic Studies, 3(3), 1-11.

Berry, M. (1998). Strategic Planning in Small High-Tech Companies. Long Range Planning. http://dx.doi.org/10.1016/S0024-6301(98)80012-5

Bracker, J. S., Keats, B. W., \& Pearson, J. N. (1988). Planning and Financial Performance among Small Firms in a Growth Industry. Strategic Management Journal, 9(6), 591-603. http://dx.doi.org/10.1002/smj.4250090606

Brown, D. M., \& Laverick, S. (1994). Measuring Corporate Performance. Long Range Planning, 27, 89-98. http://dx.doi.org/10.1016/0024-6301(94)90059-0

Carland, J. C., \& Carland, J. W. (2003). A Model of Entrepreneurial Planning and its Effect on Performance. Paper presented at the ASBE Annual Conference-Building Bridges to the Future, Houston, Texas.

Cooper \& Schindler. (2006). Research Design: Qualitative and Quantitative Approaches. Thousand Oaks, CA, Sage.

Gerber, M. E. (2001). The E-Myth Revisited: Why Most Small Businesses Don't Work and What to do about it. New York. Harper Collins. 
Gibson, B., \& Cassar, G. (2002).Planning Behaviour Variables in Small Firms. Journal of Small Business Management, 40(3), 171-86. http://dx.doi.org/10.1111/1540-627X.00049

Gibson, B., \& Cassar, G. (2005). Longitudinal Analysis of Relationships between Planning and Performance in Small Firms. Small Business Economics, 25(3), 207-222. http://dx.doi.org/10.1007/s11187-003-6458-4

Grant, R. M. (2008). A Framework Linking Intangible Resources and Capabilities to Sustainable Competitive Advantage. Strategic Management Journal, 14(8), 607-618.

Hormozi, A. M., Sutton G. S., McMinn, R. D., \& Lucio, W. (2002). Business Plans for New or Small Businesses: Paving the Path to Success. Management Decision, 40(8), 755-763. http://dx.doi.org/10.1108/00251740210437725

Jennings, P., \& Beaver, G. (1997). The Performance and Competitive Advantage of Small Firms: A Management Perspective. International Small Business Journal, 15(2). http://dx.doi.org/10.1177/0266242697152004

Kargar, J., \& Parnell, J. A. (1996). Strategic Planning Emphasis and Planning Satisfaction in Small Firms; An Empirical Investigation. Journal of Business Strategies, 13(1), 42-64.

Kothari, C. R. (2004). Research Methodology: Methods and Techniques (2nd ed.). Oxford University Press, Oxford.

Lumpkin, G. T. (1998). Do New Entrant Firms Have an Entrepreneurial Orientation? Paper Presented at the annual meeting of the Academy of Management, San Diego, CA.

Lumpkin, G. T., \& Dess, G. G. (2001). Linking Two Dimensions of Entrepreneurial Orientation to Firm Performance: The Moderating Role of Environment and Industry Life Cycle. Journal of Business Venturing, 16, 429-451. http://dx.doi.org/10.1016/S0883-9026(00)00048-3

Lurie, S. M. (1987). Strategic Business Planning for the Small to Medium-Sized Company. The CPA Journal, 57(6), 90-92.

Metcalfe, S., Ramlogan, R., \& Uyarra, E. (2003).Competition, Innovation and Development: The Instituted Connection. Institutions and Economic Development, 1(1).

Miller, C. C., \& Cardinal, L. B. (1994). Strategic Planning and Firm Performance: A Synthesis of More Than Two Decades of Research. Academy of Management Journal, 37(6), 1649-1665. http://dx.doi.org/10.2307/256804

Mohutsiwa, M. (2012). Strategic Entrepreneurship and Performance of Small and Medium Enterprises in South Africa. A research Report Submitted to the Faculty of Commerce, Law and Management, University of the Witwatersrand, in Partial Fulfillment of the Requirements for the Degree of Master of Management in Entrepreneurship and New Venture Creation. Johannesburg, South Africa.

Njanja, W. L. (2009). An Investigation into Management Strategies Affecting Performance of Micro, Small and Medium Enterprises (MSMEs) in Kenya. Submitted in Accordance 
with the Requirements for the Degree of Doctor of Commerce in the Subject Business Management and Policy at the University of South Africa.

Onugu, B. A. N. (2005). Small and Medium Enterprises in Nigeria (SMEs): Problem and Prospect. Being a Dissertation Submitted to St. Clement University in Partial Fulfilment of the Degree of Doctor of Philosophy in Management.

Pearce II, J. A., \& Robinson, Jr. R. B. (2011). Strategic Management (12th ed.). New York.

Pralahad, C. K., \& Hamel, G. (1990). The Core Competence of the Corporation. Harvard Business Review, 68, 79-91. Prentice-Hall Publishers, Englewood Cliffs, New Jersey, USA.

Raduan, C. R., Jegak, U., \& Alimin, I. I. (2009). A Conceptual Framework of the Relationship between Organizational Resources, Capabilities, Systems, Competitive Advantage and Performance. Research Journal of International Studies, 12, 45-58.

Republic of Kenya (2005). Development of Micro and Small Enterprises for Employment and Wealth Creation. Sessional Paper No. 2. Government Printer, Nairobi, Kenya.

Republic of Kenya. (1986). Economic Management for Renewed Growth. Sessional Paper No. 2 Government Printer, Nairobi, Kenya.

Republic of Kenya. (2008).Vision 2030. Government Printer, Nairobi, Kenya.

Schwenk, C., \& Shrader, C. B. (1993). Effects of Formal Strategic Planning on Financial Performance in Small Firms. A Meta-Analysis Entrepreneurship Theory and Practice, 17(3), 53-64.

The Economist. (2012). Small Is Not Beautiful: Why Small Firms are Less Wonderful Than you Think.

Wernerfelt, B. (1984). A Resource Based View of the Firm. Strategic Management Journal, 5, 171-180. http://dx.doi.org/10.1002/smj.4250050207

\section{Copyright Disclaimer}

Copyright reserved by the author(s).

This article is an open-access article distributed under the terms and conditions of the Creative Commons Attribution license (http://creativecommons.org/licenses/b 